\section{Ethical Lingua}

Journal of Language Teaching and Literature

ISSN 2355-3448 (Print)

ISSN 2540-9190 (Online)

Volume 4, Number 2, August 2017

pp. $151-164$.

\title{
Improving Students' Vocabulary Mastery by Using
}

\section{Authentic Materials through Communicative Approach}

\author{
Umar $^{1}$ and Irmayanti ${ }^{2}$ \\ umarsahaf@yahoo.com \\ ${ }^{1}$ Universitas Sulawesi Barat, Indonesia \\ ${ }^{2}$ SMP Negeri 1 Alu, Polewali Mandar Sulawesi Barat, Indonesia \\ Accepted : 23 July 2017 \\ URL : : http://journal.uncp.ac.id/index.php/ethicallingua/article/view/628
}

\begin{abstract}
The research aimed at finding out whether or not using of authentic materials through communicative approach improves the vocabulary of the students. This applied a pre-experimental method. The population of the research was the second grades students of a state high school comprising four classes and one of which chosen as the sample by using purposive sampling. The sample consisted of thirty two. The data were collected by using vocabulary test that consisted 20 items. The proce 4 of collecting data was presented in chronological order as pre-test given before treatment and then post-test was giving after treatment as students' achievement. The data analysis showed that there was significant difference of the students' vocabulary achievement after giving treatment by using authentic materials through communicative approach. It was proved by the mean score of pre-test was 5.97 and the mean of post-test was 7.82. The data was analyzed by using t-test was higher than t-table value. The value of t-test was 9 , while t-table value was 1.695 at the 0.05 level significance. Based on the result above, the writer concludes that the use of authentic material through communicative approach improves the students' vocabulary mastery.
\end{abstract}

Keywords: vocabulary mastery, authentic material, communicative approach. 


\section{Introduction}

Teaching English in our country has been developing extensively because it is functioned as an international language in the world. Therefore, Indonesia government has brought it into school curriculum since at the elementary school. English in our education program has become compulsory subject. It is though from junior high school up to university. Even today, some elementary school included this subject as a local content.

The study of English should be given priority, and in fact, English is the only foreign language taught as a compulsory subject in school for academic purpose and as a mean of communication. However, the result of teaching is still relatively low. In most of foreign language teaching situation, there are four perennial factors that influence in it process like teacher, materials, place, and time. EFL materials play a crucial role because they are the main teaching and learning aids. The role of materials is one of the important factors in teaching.

Learning process is closely linked to the student learning success. Ricards \& Rodgers (1986: 26) state that the rote of instructional materials within and individual instructional system might include into some specification such as Materials will allow learners to progress oat their own raters of learning, materials will allow for different styles of learning, materials will provide opportunities for independent study and use, and materials will provide opportunities for self- evaluation and progression in learning.

Other perennial factors are the teachers. In here, the teachers should have broader knowledge of the kinds of EFL materials and selecting and developing materials for their classroom use. They are also responding for making and choosing a good material. The good materials should link with the student's need and interest. Nunan (1991: 209) states that the materials are consistent with the needs and interest of learners. They are intended to serve as well as being in the harmony with institutional ideologies on the nature of language teaching.

The regular materials make the learner get bored and discourage to learn. If learner has got bored, one factor of the successful learning has gone. As Ur (1996: 23) states that boredom is not only unpleasant feeling in itself, it also leads to learner in attention, low motivation and ultimately less learning. To avoid it, the various materials are needed. It will make learners interested in it and can support their spirit to learn.

The variety of material is also needed in vocabulary. Vocabulary is really an important aspect, especially for understanding the English test even a simple one, without understanding students will find some difficulties to cover the test. Allen (1983: 1) says that experienced teacher of English as a second language know very well how important vocabulary is. They know that students must learn 
thousands of words that speakers and writers of English use. Through vocabulary, we can make some sentences, understand passage and also express our ideas effectively and efficiently besides mastering grammar.

It is clear that knowledge of vocabulary can positively facilitate the student to use English effectively in their communication. Learning vocabulary is very important for students. Aminah (1993: 35) found that the low achievement of the student in reading comprehension was influenced by the lack vocabulary. The lack of student's vocabulary may come from both the students as learners, their laziness in memorizing a number of words required, the lack of interest and motivation in learning English and the teacher as instructors. English teacher are expected to be more creative in making and giving materials to the students to encourage them in vocabulary. One way to make students interested in learning vocabulary is the materials which are presented by a teacher should be interesting and can fulfill their curious and intellect because it is authenticity increases the interest to search.

There are many references to authentic material in the ELT literature. Book and journals contain through explanations of why it should or should not be included in lessons, and how it is to be used or best exploited. But the teachers who support the use of authentic material have in common one idea are "exposure". In other words, the benefit students get from being exposed to the language in authentic materials.

Ellis and Johnson (1994: 54), state that authentic material may provide-the core of a very specialized course if the course objective is. For example: to increase vocabulary. It may also be very relevant to the learner's special interest and thus be used to fill gaps in published for learners of English.

Communicative approach that focus on the use of language as a means of communication. In teaching language through communicative approach, the teacher should be able to stimulate the students to express their ideas or opinion creatively and communicatively through some communicative activities. It can be seen the student's- were not stimulated with the materials which applied during the class because they were asked by their teacher to do their text book exercise regularly then it was checked and returned without giving them some correction in terms of question- answer session. The student's boredom can be seen clearly while used that regular material in here text book where most of them just cheating their friend's worked did another activities. The student's achievement in vocabulary cannot be seen automatically during the class, because the teacher way of teaching lack of communicative approach even communicative activities in the classroom.

Based on the background above the researcher formulated research question as follows: Does the use of authentic material through communicative approach improve the students' vocabulary mastery? 
The finding of this research is expected to be a piece of useful of information and references for both the teacher and students in improving the teaching of English in general and vocabulary in particular by using authentic materials through communicative approach.

\section{The Concepts of Vocabulary}

According to Webster's Third New International Dictionary, vocabulary is a list or collection of words and phrases usually alphabetically arranged and explained or defined, as in a dictionary or glossary.

According to Nuttal in Nikmawati (1993: 6) active vocabulary consists of words that we use and know well to use by ourselves, and passive vocabulary consist of word that we understand approximately when we met them but cannot use them. Good (1959) defines that vocabulary as the words having meaning when heard or seen even though not produced by the individual hem self to communicate with others is the words that considered essential for minimal use of a language. Gove (1966) states that vocabulary is a sum of words of a language that employed by individual, group, or work in relation to a subject.

Hornby (1974) defines that vocabulary is the total number of words which (with the rules of combining them) make up language. Vocabulary is words known to or used by a person in a trade profession, etc. usually with definitions or translations. Forwarding the difference of the vocabulary use, Hunddleston (1954: 1-2) who deals with lexicon, says that (1) Vocabulary is content and function words of a language which are earned so thoroughly, that they become a part of the child's understanding, speaking, letter reading and writing. (2) Vocabulary is words having meaning when heard or seen even though the individual produces it when communicating with others. The first definition is likely to be related to psycholinguistics because it is sometime in connection with the child language development. While, the second one seems to reveal the presence of passive or receptive vocabulary. Harmer (1991) divides vocabulary into two types: 1) Active vocabulary refers to vocabulary that has been learned by the students. They are expected to be able to use it. 2) Passive vocabulary refers to words which students will recognize when they meet them, but they probably not are able to produce it.

Vocabulary is the stock of lexical item in a language. For the purpose of learning and teaching activities, it can be classified into two kinds; receptive and productive vocabulary. Receptive vocabulary refers to words for lexical items which only can be recognized and comprehended in the context of reading and listening material. Productive vocabulary refers to words which can be recalled and used appropriately in writing and speech. Sometimes they are so difficult to be distinguished because sometimes a word that a student has in his receptive store may suddenly become productive if the situation or context provokes to be permanent state of affairs. 
Good (1959) adds the third kind of vocabulary. It is reserved on potential vocabulary that consist of words that the individual does not know but they interpret them form their context or by reason of his background knowledge. Schil (1967) states that there are three kinds of vocabulary, namely active, reserve, and productive vocabulary. Active vocabulary refers to words that we use frequently in speeding. Reserve vocabulary refers to words that we know but rarely used we are not sure. Productive vocabulary refers to word that we use vaguely but we are not sure their meaning. We never use them either in speaking or writing. We know that because we have seen them previously.

For more specific meaning, Good (1959) divides vocabulary into four kinds, they are: 1) Oral vocabulary refers to words that a person employs them in expressing ideas orally and actively; 2) Writing vocabulary refers to words that commonly used in writing; 3) Listening vocabulary refers to word that a person can understand when they are heard; and 4) Reading vocabulary refers to words that someone can recognize them when he finds them in written form.

Wallace (1982) indicates the main principles of learning and teaching vocabulary as follows:

1. Aims

The teacher should know the aims of the words taught.

2. Quantity

The number of new words which students should possess and learn, must be clear.

3. Need

It is necessary to select the words which teachers serve to students. Its selection process is based on the aims of the course and the objective of the individual lesson and student's background and language need.

4. Frequent exposure and repetition

There is need of a certain amount of repetition until there is evidence that students learn the target words.

5. Meaningful Presentation

In presenting the vocabulary lesson, students should have a clear and specific understanding of what the words refer to or denote. Its presentation should be perfect, meaningful and unambiguous.

6. Situation Presentation

The way in the presenting the words should be appropriate to student's situation.

7. Presenting in Context

Through reading material, new words or unfamiliar words can be presented as a medium in teaching vocabulary.

8. Learning vocabulary in the mother tongue and target language In teaching the target words, teacher may use words of the mother as a tool 
of compare similarities and differences of the words.

9. Guessing procedure in learning vocabulary

Guessing is a way in learning vocabulary. It leads students to think the meaning of the word taught.

\section{The Concept of Authentic Material}

Most people associates the term "language-learning materials" with course book, because that has been their main experience of using materials. However, authentic material here is used to refer to anything which is used by teachers or learners to facilitate the learning of a language.

Ellis and Johnson (1994: 157), state that authentic material is any kind of material that taken from the real world not specifically created for the purposes of language teaching. The materials could be obviously be text, visuals or audio material; it can be media such as tickets, menus, maps and timetables, cassettes, videos, photocopy, CD-rooms, dictionaries, grammar book; or it can be object such as products, equipment, components or models. They could also be newspaper, food packages, photographs, live talks by invited native speakers, instructions given by teacher, tasks written, and cards or discussion between learners.

Widdowson's (1990) differentiation of the terms "authentic" and "genuine material", authentic would be material designed for native speakers of English used in the classroom in a way similar to the one it was designed for. For example, radio news report. Most of the time, though, this material is used in a genuine way, in other words, not in the way it was intended, but in a somewhat artificial way. The definition of authentic material is also taken from Peacock (1997) materials that have been produced to fulfill some social purpose in the language community.

According to Ellis and Johnson (1994), there are three types of authentic material, namely text, regalia, and object. Text consist of two kinds namely written text such as magazines, newspaper and commercial books and audio text such as films, radio, broadcasting and television. Regalia is an object taken from real environment such as menus, tickets, maps, time tables, brochure and pamphlets. Object consist of products, equipment components or models.

According to Richard \& Roger (1986), there are two types of authentic materials, namely: 1) language based realities which consist of magazines, advertisement and newspaper; and 2) Graphic that is visual sources around which communicative activities can be built such as maps, pictures, symbols graphs and charts.

The importance of using authentic material in the classroom is significant for many reasons, amongst which are: 
1. Student is exposed to real discourse, as in videos interviews with famous people where intermediate students listen for gist.

2. Authentic materials keep students informed about what happening in the world, so they have an intrinsic educational value. As teachers, we are educators working within the school system, so education and general development are part of our responsibilities (Sanderson, 1999).

3. Textbooks often do not include incidental or improper English.

4. They can produce a sense of achievement, for example brochure and menu.

5. The same piece of material can be used differently if depending on the task.

6. Language change is reflected in the materials so that the student and teachers can keep abreast of such changes.

7. Reading texts are ideal to teach or practice some of micro-skills mentioned by Richards (1983), for example basic students listen to news reports and they are asked to identify the names of countries, famous people, etc. (ability to detect key words).

8. Books, articles, newspaper, and so contain a wide variety of text types, language styles not easily found in conventional teaching materials.

9. They can encourage reading for pleasure because they are likely to contain topics of interest to learners, especially if students are given the chance to have a say about the topics or kinds of authentic materials to be used.

\section{Communicative Approach}

The communicative approach in language teaching starts from a theory of language as communication. The characteristic of the communicative view of language are:

1. Language is a system for the expression of meaning.

2. The primarily function of language is for interaction and communication.

3. The structure of language reflects it's functional and communicative uses.

4. The primary units of language are not merely its grammatical and structural features, but categories of functional and communicative meaning exemplified in discourse.

The goal communicative approach in language teaching is developed what Hymes (1972) referred to as "communicative competence". Savignon (1972) defines that communicative setting that is a dynamic exchange in which linguistic competence must adapt itself to the total information input. According to Hymes (1972), a person who acquires communicative competence acquires both knowledge and ability for language use with respect to: 1 ) whether (and to what degree) something is formally possible; 2) whether (and to what degree) something is possible in virtue of the means of implementation available; 3) whether (and to what degree) something is appropriate adequate in relation to a context in which it's used and evaluated; and 4) whether (and to what degree) something is in fact done, actually performed, and what it's during entails. 
Nunan (1991) and Brown (1994) offer five features to characterize communicate approach in language teaching. An emphasis on learning to communicate through interaction in the target language: 1) the introduction of the authentic text into the learning situation. The provision of the opportunities for the learner to focus not only on language but also on the learning process itself. 2) An enhancement of the learner's own personal experience as important contributing elements to classroom learning. 3) An attempt to link classroom language learning with language activation outside the classroom.

Finacchioario and Brumfit (1983) state that the features of the communicative approach as follows:

1. Meaning is paramount.

2. Dialogues, if used, center on communicative functions and not normally memorized.

3. Conceptualization is a basic premise.

4. Language learning is learning to communicate.

5. Effective communication is sought.

6. Drilling may occur but peripherally.

7. Comprehensible pronunciation is sought.

8. Any device that helps the learner is accepted varying according to their age, interest.

9. Attempts to communicate may be encouraged from the very beginning.

10. Judicious use of native language is accepted where feasible.

11. Translation may be used where students need or benefit from it.

12. Reading and writing can start from the first day, if desired.

13. The target linguistic system will be learned through the process of struggling to communicate.

14. Communicative competence is desire goal i.e. the ability to use the linguistic system effectively and appropriately.

15. Linguistics variation is a central concept in materials and methodology.

16. Sequencing is determined by any consideration of content, function or meaning which maintains interest.

17. Teachers help learners in any way that motivates them to work with the language.

18. Language $s$ created by the individual often through trial and error.

19. Fluency and acceptable language is the primary goal; accuracy is judge not in the abstract but in context.

20. Students are expected to interact with other people, either in the flesh through pair and group work or in their writings.

21. The teacher cannot know exactly what language the students will use.

22. Intrinsic motivation will spring from an interest in what is being communicated by the language. 


\section{Research Methodology}

This research applied pre-experimental with one group pre-test and post-test design. It was intended to test the hypothesis concerning differences of two scores. The design involved one group which was pre-test and exposed to the treatment and post-test was administered to measure treatment effects.

The research has two variables. The first was the use of authentic material through communicative approach in teaching vocabulary as independent variable and the second one was the student's vocabulary achievement in terms of noun and verb as dependent variable.

The research used purposive sampling technique that was applied due to the fact that the chosen class consisted of 32 students included in authentic sample English language class. In this case, the sample was the second grade students of SMAN 1 Sinjai Timur especially class XI Language.

The instrument of this research was vocabulary test in the form of question consisted of pre-test and post-test. Tie test consisted of 20 Items. Pre-test was intended to find out the prior level knowledge of student's vocabulary specially in cooking term related with recipe while the post-test was intended to find out the students' achievement after treatment.

The procedure of collecting data was presented as follows:

1. Pre-test

A pre-test was administered to assess the students' prior knowledge. In this section, the students were given some questions that have been related with cooking term for 90 minutes to answer.

\section{Treatment}

In giving treatment, the writer taught them by using authentic materials through communicative activities. These treatments were conducted in the classroom into six meetings and each meeting was running 90 minutes $(2 \times 45$ minutes). In the first and the second meetings, the writer explained and gave some vocabulary related with recipe by bringing authentic materials of each recipe as teaching materials in the classroom.

In the third and fourth meetings, the writer was practicing on both recipes in front of the classroom by bringing food appliances and the ingredients of the recipe which will be demonstrated.

\section{Post-test}

The post test was given after doing treatment. The content of the post- test is the same as the pretest. The aim of the post-test is to know the student's vocabulary achievement after giving the treatment. 
The data of pre-test and post-test were analyzed by the following steps:

1. Scoring the student's answer in pre-test by using the following formula:

$$
\text { Score }=\frac{\text { Student's correct answer }}{\text { Highest score }} \times 10
$$

2. Classifying of the student's ability based on the vocabulary score classification, as follows:

Table 1. The student's score classification in vocabulary ability

\begin{tabular}{cl}
\hline Score & \multicolumn{1}{c}{ Classification } \\
\hline $9.6-10$ & Is classified as excellent \\
$8.6-9.5$ & Is classified as very good \\
$7.6-8.5$ & Is classified as good \\
$6.6-7.5$ & Is classified as fairly good \\
$5.5-6.5$ & Is classified as fair \\
$3.6-5.5$ & Is classified as poor \\
$0.0-3.5$ & Is classified as very poor \\
\hline
\end{tabular}

\section{Findings}

The students' pre-test and post-test

Table 2. The Students' Score in Pre-test and post-test

\begin{tabular}{ccccccc}
\hline No & Classification & Score & F Pre-test & $(\%)$ & F Post test & $(\%)$ \\
\hline 1 & Excellent & $96-10$ & - & - & 1 & $3 \%$ \\
2 & Very Good & $86-95$ & - & - & 6 & $19 \%$ \\
3 & Good & $76-85$ & 3 & $9 \%$ & 13 & $41 \%$ \\
4 & Fairly Good & $66-75$ & 7 & $22 \%$ & 10 & $31 \%$ \\
5 & Fair & $56-65$ & 12 & $38 \%$ & 1 & $3 \%$ \\
6 & Poor & $46-55$ & 9 & $28 \%$ & 1 & $3 \%$ \\
7 & Very Poor & $0-45$ & 1 & $3 \%$ & - & - \\
\hline
\end{tabular}

Table 2 above showed that there were $3(9 \%)$ students got "good" score, 7 $(22 \%)$ students got "fairly good" score, 12 (3 8\%) students got "fair" score, 9 $(28 \%)$ students got "poor" score, $1(3 \%)$ students got "very poor" score, and none of them got "excellent" and very good score. While the frequency and rate percentage of the students post-test can be seen from the table. There was 1 $(3 \%)$ students got excellent score, $6(19 \%)$ students got very good score, 13 $(41 \%)$ students got good score, $10(31 \%)$ students got fairly good score, $1(3 \%)$ students got fair score, $1(3 \%)$ students got poor score, and none of them got very poor score.

Based on the result above, it can be concluded that the rate percentage in the post-test was higher than the rate percentage in the pre-test 
After calculating the result of the students' pretest and post-test; the mean score and standard deviation are presented in the following table to find out whether there is significant difference between the pre-test and post-test.

Table 3. The Mean Score and Standard Deviation of Pre-test and Post-test Score

\begin{tabular}{cccc}
\hline \multicolumn{2}{c}{ Mean Score } & \multicolumn{2}{c}{ Standard Deviation } \\
\hline Pre-test & Post-test & Pre-test & Post-test \\
\hline 5.97 & 7.82 & 2.7 & 0.988 \\
\hline
\end{tabular}

The data on the table above shows that the mean score of post-test was higher than the mean score of pre-test. While the standard deviation of students' pre-test was higher than post-test. The students' vocabulary got a significant development gain, which are 1.85 .

In order to know whether or not the difference between pre-test and posttest is statistically significant, the t-test statistical analysis for non-independent sample was employed. The result of the t-test is $t 9$.

Table 4. The T-test of Students' Vocabulary Achievement

\begin{tabular}{cc}
\hline T-test & T-table \\
\hline 9 & 1.695 \\
\hline
\end{tabular}

For the level of significance $(p)=0.05$ and $d f=31$, then the value of the 1 table is 1.695. Thus the result of t-test is greater than the value oft-table (9> 1.695). It means that there is significant difference between the pre-test and post-test of the students in vocabulary achievement after having treatment by using authentic materials through communicative approach is a delightful way to improve the students' vocabulary.

Since the result of the $t$ value (9) is greater than the t-table value (1.695) means that there is significant different between the mean score of the students' pre-test and the mean score of the students post-test after having treatment by using authentic materials through communicative approach.

\section{Discussion}

The result of pre-test and post-test showed that the use of authentic materials through communicative approach as a teaching medium gave a good effect in improving the students' vocabulary. It is worth discussing here how the students improving their vocabulary. When the pre-test was given, most of the students found difficult to answer the question of the test. They only guessed to choice the best answer and some of them just cheating their friends' work. It because they have low prior knowledge of the material in this case is recipe and lack of vocabulary. Consequently, the score gained was lower as can be seen in the result of frequency and rate percentage of the students' score pre-test. 
The use of authentic materials through communicative approach can give a good impact and effect to influence and to encourage the students to participate actively in communicative activity. It can be also seen when the treatment was conducted. They were interested to learn the material in this case recipe. This teaching technique can attract the students' attention and make them enjoy learning in classroom. The students' attention can be seen in the giving treatment.

They can easily to recognize and to memorize the name of things. Moreover they can interact with the materials and communicative in small group. In conjunction with the implementation of authentic materials through communicative approach, it affected the students' interest not only to know about something but also to participate actively in communicative activities.

The evidence shows that the students got significant improvement. After giving treatment, the students built up some words by classify nouns, verbs, and find out the meaning correctly. The description of the data collected through the test as explained in the previous section shows that the students' vocabulary achievement was good. It was supported by the scoring classification of the result of students post-test. Based on the result of t-test, the researcher found that there was significant difference between the result of the test before and after teaching and learning process of the vocabulary. This finding supported by River (1978: 44) state that authentic materials are deliberately used to increase the learners' knowledge or experience of the language. Authentic materials can bring students into contact with language as it is used in the cultured to meet actual communication needs.

\section{Conclusion \& Suggestion}

Based on the findings and discussions, it can be concluded that the use of materials through communicative approach in the classroom can improve the student's achievement in English especially on their vocabulary. It can be seen from the t- test which shows that there is significant difference between the result of the students' pre-test and post-test after having treatment by using authentic materials through communicative approach.

It is suggested that the English teacher should not only use the teaching media which are available in school but the teacher should try to use the other teaching media, for example recipe, tickets, and brochure. Moreover, the using of authentic materials through communicative approach should be given to the students as often as possible in every meeting. 


\section{References}

Allen, VF. (1983). Techniques in Teaching Vocabulary. New York: Oxford University Press.

Arafah, Syarifah. (2001). Using Cartoon F as a Teaching Device to Enrich Students Vocabulary of the Third Semester Students of English Department of FBS UNM. Unpublished Thesis. UNM.

Arikunto, Suharsimi. (2002). Prosedur Penelitian Suatu Pendekatan Praktek. Jakarta: PT. Rineka Cipta.

Arninah. (1993). Factor Affecting the Reading Comprehension Achieveiwnt of the Sixth Seven Students of English Education Department of FBS IKIP Ujung Pandang. Unpublished Thesis. FPBS Ujung Pandang.

Brown, James \& Fred Richard. (1997). An Instruction Technology Media and Methods. Australia: Megraw - HILL Book Company.

Cook. (1991). Second Language Learning and Language Teaching. London: Edward Arnold.

Corder, S Pit. (1975). Introducing Applied Linguistics. England: Penguin Education.

Emawati. (2003). Hubungan Antara Frekuemsi Mengikuti Siaran Kuis Digital LG Dengan Prestasi. Thesis. FPBS Ujung Pandang.

Evans, Idealla \& Ron Muldof. (1978). Psychology for a Changing World. New York.

Gay, L. R. (1981). Educational Research (Competencies for Analysis and Application). Florida: Charles E, Meril Publishing CO.

Harmer, Jeremy. (1991). The Practice of English Language Teaching. London: Longman Group.

Kemp Jerrold \& Deanek, Dayton. (1985). Planning and Producing Instruction Media. Fifth Edition. New York: Harper and Raw Publisher.

Larsen, Freeman. (1986). Techniques and Principles in language Teaching. Oxford. University Press.

Madjid, Arqam. (1999). The Influence of Using the Three Dimension Media on Learning Motivation and Material Common in English Teaching to the Fourth Grade Students at SD Negeri Kompleks IKIP UP. Thesis FPBS IKI Ujung Pandang.

Nikmawati. (1993). Mastering Vocabulary through Picture at the First Semester of SMA Negeri Pario. Kab. Wajo. Thesis. FBS UNM.

Nuttal, Cristoone. (1982). Teaching Reading Skill in a Foreign Language. London: Heinemann Education Book.

Nunan, David. (1991). Language Teaching Methodology, New York: Prentice Hall.

Richards, J \& Theodore s Rodgers. 1986. Approaches And Methods in Language Teaching. Prentice Hall.

Rivers, Wilgan. (1987). Interactive Language Teaching as Communication. Oxford. University Press.

Schill, Williams. (1967). Seven Days to Faster Reading. New York: Paperback Library Inc. 
Savignon, Sandra. (1983). Communicative Competence: Theory an Classroom Practices. California: Addison Wesley Publishing Company.

Tronch, Keith \& Phill Cullen. (1976). Quality Education. Australia.

Ur. Penny. (1996). A Course in Language Teaching. Cambridge: Cambridge University Press.

Wallace, Michael J. (1982). Teaching Vocabulary. Oxford: Fleinemanu Education Book Ltd.

Widdowson, H. (1990). Aspect of Language Teaching. Oxford. Oxford University Press. Wello, Muhammad Basri \& Hafsa J Nur. (1999). An Introduction to ESP. Ujung Pandang. UNM.

Yapardi, Nirmawati. (1995). Improving Students Vocabulary Through Discovery Technique to the Second Year Students of SMP Datuk Ribandang Makassar. Makassar. Thesis. FBS UNM. 